ISBN 041590682 2, £11.99 Pbk ISBN 041590681, 637.50 Hbk

\title{
Nomadic Subjects: Embodiment and Sexual Difference in Contemporary Feminist Theory
}

Rosi Braidotti

Columbia University Press: New York, 1995

ISBN 023108235 5, f12.00 Pbk ISBN 023108234 7, f34.50 Hbk

How, if you are a postmodern feminist committed to the deconstruction of the unified subject, do you seek to retain and register some sort of feminine identity? What is the appropriate response of the feminist critic to those moves, initiated (so many would claim) in Nietzsche's writings, and continued in the contemporary neo-Nietzschean project of Derrida and others, to 'feminize' philosophy? Are these to be applauded as the beginning of the reversal of its longstanding male bias, or to be deplored as the continuation of the same hostilities by other, more covert and ingenious, means?

Both these works either themselves directly pose these questions or implicitly raise them; and both invite us to believe that it is only by bringing the perspective of sexual difference theory to bear (that of Irigaray especially, though Kristeva is also an important influence) that feminists can expect to reach any satisfactory resolution of them.

Kelly Oliver's study is the more focused of the two, though it goes under a rather ugly and misleading title (it is not so much about making a woman of Nietzsche as about exposing his womb-envious fear and fascination with the female; it is also, one might add, a text addressed as much to Freud and Derrida on the feminine as directly to the views of Nietzsche himself). The essential thesis of the book is that even those, like Nietzsche and Derrida, who more than other male thinkers have opened philosophy to its negated or marginalized 'others' (the unconscious, the body, non-meaning, even the feminine in some sense), remain closed to what she calls a 'specific feminine' and particularly to the registering of a positive, vocal, cultural, desiring maternal subject. Their engagement with 'woman' is abstract, appropriative, and inherently phallic in outlook, both in the sense that their texts tacitly presuppose the masculinity of their readers (and hence exclude a feminine subject), 
and in the sense that they refuse to acknowledge any feminine which is not conceived simply as the negative of the masculine.

This Irigarayan critique is pressed home in a series of dense and convoluted discussions of the self-parodying rhetorical strategies whereby philosophy is 'feminized' in this Nietzschean mode only through a process of emasculation which erases sexual difference and can recognize no woman or feminine other than the all-powerful phallic mother identified with mother nature. What is needed as a corrective, Oliver suggests, is a 'maternal model' or revision of thinking about the maternal such that the social and relational dimensions of mothering are fully recognized in philosophy and allowed to provide the basis for a new ethic.

All this will probably be acceptable enough to those already persuaded of the absoluteness of sexual difference and agreeable to the ultimate tracing of this in the maternal function. To those less ready to adopt the unqualified view that 'subjects and their experiences are always sexed' or to accept that the mothering role is inherently feminine, it will seem dogmatic, based on challengeable premises and politically troubling in its apparent exclusion of male participation in nurturing. It is also surely a touch idealist of Oliver to argue that if the traditional account of the child's relation to its mother is taken as a prototype for all other relationships, then we need an account of the mother-child relationship that sets up rather than cuts off, the possibility of a reciprocal relation of exchange'. Here, as elsewhere in her book, the tendency is to suppose that the task is purely one of theoretical accounting - as if appropriately erotic descriptions of early experiences would ensure the loving quality of adult relations. Unfortunately, the world is a harsher place than some of these academic recommendations seem ready to acknowledge.

Finally, one might note a number of equivocations in Oliver's reading of Derrida. Thus, within the space of a couple of pages, we are told both that 'in the name of undecidability every sex becomes masculine' and that Derrida 'turns all sexuality, insofar as it is undecidable, into the feminine'. But no doubt exposing the phallogocentrism at the heart of deconstruction's major theorist is bound to involve some tight manoeuvres, and in the end Oliver's point seems to be that Derrida does well to demolish the unified subject but should not have begun by dismantling the female - since it is necessary, she claims, in some sense to continue to rally round the identity of 'woman'.

This strikes me as a pretty questionable 'having your cake and eating it' version of deconstruction, but one, I suspect, to which Braidotti would also want, if possible, to subscribe. At any rate in a collection of essays crowded with large (and, perhaps understandably, largely unanswered) 
questions, that of how to reconcile the death of the subject with the realization of the 'feminine' is the most frequently repeated. Like Oliver, too, Braidotti is inclined to overestimate the contribution of theoretical rectitude to providing resolutions of these issues and thus correcting the oppression of women.

In this spirit she recommends the shift to a 'nomadic' understanding of the subject as alone able to resist the potential 'microfascism' of all 'hegemonies' whatever their size, and however local. Such nomadic shifts, she argues 'designate a creative sort of becoming; a performative metaphor that allows for otherwise unlikely encounters and unsuspected sources of interaction of experience and of knowledge'. They also, one might argue, make it difficult to see how you would defend any positive form of hegemony or constructive solidarity (where does it leave, for example, the politics of the neo-Gramscians and advocates of 'radical democracy'?). Braidotti clearly intends to entice us with this vision of the territories and transgressions opened up to the 'nomadic' subject, and makes a number of astute points in the course of its elaboration. But overall I found these essays rather flatly written and repetitious in their argument. A little more self-irony and some more exacting editing would have considerably added to the pleasures of this particular voyage of discovery.

Kate Soper

\section{The Practice of Love, Lesbian Sexuality and Perverse Desire}

\section{Teresa de Lauretis}

Indiana University Press, 1994

ISBN 025320878 5, f11.99 Pbk ISBN 025331681 2, \$36.95 Cloth

This book is a passionate rendering of Teresa de Lauretis' journey through psychoanalysis, structuralism, and semiotics. Her search is guided by her desire to represent her experiences of lesbian sexuality. The author consistently and vibrantly expresses her own stake in the questions she raises; this is not an abstract, ungendered, unsexualized, pseudo-scientific quest for the foundational 'truth' of lesbianism.

Part One of the book presents a critical reading of psychoanalytic texts focusing on their analyses of lesbian sexuality. De Lauretis stresses that her aim in re-reading Freud is to exemplify the discontinuities and ambiguities of his theories of sexuality: the complexities which engage our 